Sergiej MiCHALCZENKO

Uniwersytet Państwowy, Briańsk

\title{
Историк права Ф. В. Тарановский
}

C

татья посвящена жизни и научной деятельности русского историка права Ф. В. Тарановского, чье творчество изучено пока совершенно недостаточно ${ }^{1}$.

Федор Васильевич Тарановский родился 12 мая 1875 г. в г. Плонске Плоцкой губернии Царства Польского в семье потомственных дворян (по сведениям послужного списка ${ }^{2}$; по сведениям же Е. В. Спекторского, отец Тарановского происходил из православного духовенства Волыни, мать - из обедневшей польской шляхты ${ }^{3}$ ). После окончания с серебряной медалью 6-й Варшавской гимназии в 1892 г. он поступил на юридический факультет Варшавского университета.

Варшавский университет представлял собою особенное явление в палитре дореволюционной российской высшей школы. Основанный в 1816 г., он затем был закрыт и восстановлен в 1869 г. как русский университет на польской (по этническому составу населения) территории. Основной задачей университета провозглашалась русификация студенчества. Так, несмотря на то, что значительно больше половины контингента в нем составляли поляки, польский язык не преподавался, а русская история, напротив, читалась не только на историко-филологическом факультете, но и на юридическом как обязательный предмет. Состав профессоров был достаточно консервативен. За редчайшим исключением отсутствовали приват-доценты - правительство опасалось притока поляков, вместо

1 См.: Е. В. Спекторский, Жизнь и личность Ф. В. Тарановского, в: Записки Русского Научного Института, Белград 1936, Вып. 13, с. I-XX; О. А. Омельченко, Московское государство в историографическом наследии Ф. В. Тарановского, в: Развитие права и политико-правовой мысли в Московском государстве, М. 1985 , с. 51-76.

2 Российский государственный исторический архив (РГИА), Ф. 733, Оп. 155, Д. 352, Лл. 79 об. 80.

3 Е. В. Спекторский, Указ. соч., с. 1. 
этого в Варшавском университете, единственном из российских университетов, сохранили звание штатного доцента (после принятия устава 1884 г.) а также, наряду с Юрьевским, выпускную степень кандидата ${ }^{4}$. Юридический факультет, куда поступил Тарановский, кроме преподавания широкого спектра исторических дисциплин, отличался от других российских университетов еще и наличием особой кафедры славянских законодательств, которую занимал профессор Ф. Ф. Зигель. (Введенная по уставу 1863 г. во всех университетах, реально она существовала только здесь). В 1892 г. в Варшаву приехал профессором по кафедре истории русского права служивший до этого в Одессе Ф. И. Леонтович. По государственному праву лекции читал А. Л. Блок, отец поэта. Именно этих трех ученых позднее называл Тарановский в качестве своих учителей. Сравнительный метод Леонтовича, широкая славяноведческая подготовка Зигеля и позитивистские по духу лекции Блока, анализировавшего Конта, оказали влияние на формирование мировоззрения ученого. Непосредственным руководителем первой студенческой работы Тарановского стал Леонтович ${ }^{5}$. Именно по его предложению Тарановский в качестве темы медального сочинения, дающего право получения степени кандидата, выбрал историю магдебургского права на Украине. Несмотря на кажущуюся неновизну (магдебургское право было предметом изучения в трудах В. Б. Антоновича, М. Ф. Владимирского-Буданова, А. Ф. Кистяковского), тема была достаточно актуальна, поскольку два основных исследователя доказывали диаметрально противоположные - положения: Антонович настаивал на чужеродности магдебургского права для Украины, именно оно, по мнению историка, привело города Украины к упадку. Владимирский-Буданов, исследовавший действие магдебургского права в городах Польши и Литвы, пришел к выводу иному, он считал, что основной причиной „падения” городов были их привилегии. Но так как привилегии получались городами при пожаловании им магдебургского права, то, фактически, оно оценивалось историком также негативно. Правда, Владимирский-Буданов не считал, как Антонович, что магдебургское право ввиду его чужеродности не применялось в славянских землях - он думал, что право действовало.

4 См.: Н. Дубровский, Офиичиальная наука в Царстве Польском: Варшавский университет по личным воспоминаниям и впечатлениям, СПб. 1908, с. 101.

5 См.: Варшавские университетские известия, 1894, Приложение. 
И именно по иностранным источникам. „Срединную” точку зрения высказал Кистяковский, полагавший, что магдебургское право действовало по польским книгам, но видоизменялось под влиянием местных обычаев ${ }^{6}$.

В процессе изучения Тарановским источников оказалось, что Антонович допустил ряд ошибок, обратившись к так называемому Саксону Щербича, в то время как нужно было - к книгам Троицкого. Именно поэтому Антонович считал, что ссылки на магдебургское право при судебных решениях были формальными, тогда как они были вполне действенными, но совершались по иному источнику. В итоге Тарановский фактически присоединился к точке зрения Кистяковского об использовании на Украине и в Белоруссии польских переводов текстов магдебургского права при известном влиянии местных обычаев ${ }^{7}$. Правда, Тарановский полагал и Саксон Щербича, и книги Троицкого скорее популярным изложением законов, нежели строгим переводом оригиналов ${ }^{8}$. Общий итог исследования был таков: рецепция магдебургского права имела место, но осуществлялась не законодательным путем, а прецедентным, через судебную практику с использованием частных юридических сборников. Основанные на кропотливом источниковедческом анализе, выводы Тарановского позволили занять его первой книге важное место среди трудов по истории магдебургского права.

После успешного окончания университета закономерным явилось оставление его при университете, при кафедре истории русского права, для приготовления к профессорскому званию. „Аспирантура” Тарановского продолжалась с ноября 1896 по январь 1899 г. и не закончилась защитой диссертации. Недостаток источников не позволяет выяснить причину затяжки. Возможно, таковой был слишком широкий план подготовки к магистерским испытаниям, составленный руководителем Тарановского Леонтовичем. „С целью всесто-

6 М. Ф. Владимирский-Буданов, Немечкое право в Польше и Литве, СПб. 1868; В. Б. Антонович, Исследование о городах Юго-Западного края, ч. V, т. 1, АЮЗР, Киев 1869; А. Ф. Кистяковский, Очерк исторических сведений о своде законов..., „Университет известия”, Киев 1878, № 12, с. 994.

7 Ф. В. Тарановский, Обзор памятников магдебургского права западно-русских городов литовской эпохи: Историко-юридическое исследование, Варшава 1897 , c. $38,55$.

8 Там же, с. 186. 
роннего изучения науки истории русского права, как в современном ее состоянии, так и на разных стадиях ее развития" стипендиат Тарановский должен был изучить громадное число источников и литературы не только по собственно русскому праву, но и по византийскому, и монгольскому (так как было соответствующее влияние в древний период), а главное, руководствуясь сравнительным методом, изучить практически все славянские и многие из западноевропейских законодательств. „По истории славянского права желательно изучение древнейших памятников права польского, чешского, хорватского и сербского [...] со знакомством, с главнейшими трудами славянских историков-юристов (Мацеевского, Бандтке, Иречека и др.), - писал Леонтович. - По истории западноевропейского права, в особенности, желательно ознакомление с древнейшими источниками, в особенности, с leges barbarorum и средневековым городским правом вообще, и с правам магдебургским в отдельности. Наконец, ради выяснения основных вопросов об исходных моментах в развитии правовых институтов, желательно было бы общее ознакомление с приемами изучения, применительно к истории права, данных сравнительного языкознания (в особенности, - правовой терминологии), этнологии, мифологии и вообще сравнительного изучения народного быта эпохи первобытной культуры"9. Столь объемный план практически не оставлял времени для подготовки диссертации. К сожалению, в доступных источниках отсутствует формулировка ее темы: ведь если Тарановский был оставлен при кафедре истории русского права, то тема должна была соответствовать специальности; диссертация же, защищенная им в 1905 г., была посвящена вопросам, далеким от истории русского права, так что, видимо, произошло изменение темы исследования.

После завершения ,,аспирантского” срока Тарановский почти сразу был зачислен исполняющим должность доцента Варшавского университета по кафедре энциклопедии юридических и политических наук, так как кафедра истории русского права была занята Леонтовичем; читавших же спецкурсы приват-доцентов, как уже отмечалось, устав Варшавского университета не предполагал. Преподавательская деятельность Тарановского в Варшаве продолжалась недолго формально до 1906 г., а реально до 1905 г. (в этом году ввиду бойкота

9 РГИА, Ф. 733, Оп. 151, Д. 33, Лл. 62-62 об. 
студентами-поляками университет перестал функционировать как учебное учреждение и до 1908 г. существовал только как научное). Менее трех лет преподавал Тарановский энциклопедию права - уже к 1902 г. стала ясна невозможность дальнейшего преподавания истории русского права Леонтовичем, он по болезни и возрасту ушел в отставку и с 1903 г. Тарановский перешел на его кафедру ${ }^{10}$. Но магистерская диссертация была написана им все же по теории права. Называлась она „Юридический метод в государственной науке: Очерк развития его в Германии. Историко-методологическое исследование" (Варшава, 1904) и была посвящена подробному исследованию весьма частного философско-правового вопроса, продолжая до некоторой степени идеи и сюжеты, намеченные Тарановским в его вступительной лекции к курсу энциклопедии права. (Лекция была прочитана в 1899 г. и рассказывала о взглядах Р. Иеринга ${ }^{11}$.) Защита диссертации состоялась в октябре 1905 г., а годом позже Тарановский стал экстраординарным профессором Демидовского юридического лицея в Ярославле „вследствие известного распадения Варшавского университета", как он писал Н. П. Павлову-Сильванскому $^{12}$. По справедливому предположению О. А. Омельченко, не последнюю роль в этом сыграла материальная неустроенность Тарановского, так как значительную долю профессорских доходов составляли студенческие гонорары за лекции, а поскольку занятий не было, то и гонорары исчезли ${ }^{13}$. Правда, оказалось, что в лицее, несмотря на его равные права с университетами, плата взимается не со всех студентов - иначе сложно было бы привлечь желающих в него поступить при близости Москвы.

В Ярославль Тарановский поехал, видимо, без большого желания (позже он всегда подчеркивал свою приверженность западу России) - вначале он предполагал занять кафедру государственного права в Харькове. Но несмотря на активную поддержку харьковского про-

10 „Леонтович, не возвращаясь с Кавказа, подал оттуда в отставку и кафедра освободилась”, писал он 3 ноября 1902 г. Спекторскому. (Институт рукописи Центральной научной библиотеки им. В. И. Вернадского НАН Украины (ИР ЦНБ), Ф. III, № 56746, Л. 1.).

11 Ф. В. Тарановский, Интерес и нравственный долг в праве, Варшава 1899.

12 Письма Ф. В. Тарановского Н. П. Павлову-Сильванскому, в: публ. С. И. Михальченко, Проблемы социильной истории Европь: от античности до нового времени, Брянск 1995, с. 178.

13 О. А. Омельченко, Указ. соч., с. 56. 
фессора Н. А. Максимейко, кафедра была отдана профессору Демидовского лицея Н. И. Палиенко. Тарановский, таким образом, был перемещен на место Палиенко ${ }^{14}$. Несмотря на сложные обстоятельства своего появления в Ярославле, вначале Тарановскому понравилось в этом небольшом (около 80 тысяч жителей) северном городе. Здесь „живется хорошо в душевном смысле, - писал он своему другу Спекторскому, оставшемуся в Варшаве. - Здесь Вы чувствуете себя частицей великого, но несчастного народа. Сознаете обязанности нести в него свет. Говорю Вам не как увлекающийся юноша, а как муж, не утративший способности чувствовать, что я здесь перерождаюсь. Здесь грешно уклоняться от общественной жизни"15. И Тарановский развил в Ярославле бурную научную и общественную деятельность. Он состоял членом правления общественной библиотеки, был вице-председателем архивной комиссии. „За дело это возьмусь горячо, - уверял он Спекторского, - пройду таким образом курс архивного дела"16. Действительно, археографическая работа Тарановского в Ярославле была ознаменована серьезными достижениями: в 1907-1908 гг. вышли в свет собранные и прокомментированные ученым указные книги и дела Угличской провинциальной канцелярии 1719-1728 гг., куда вошли „наиболее интересные указы, челобитные и образцы делопроизводства"17. В Ярославле же Тарановский активно сотрудничал с издававшимся лицеем журналом „Юридическая библиография", в котором поместил несколько рецензий, в том числе на книги Ф. И. Леонтовича, Н. П. Павлова-Сильванского, Б. А. Кистяковского, Е. В. Спекторского, Н. А. Рожкова и др ${ }^{18}$.

Не остался Тарановский и в стороне от общественно-политических проблем своей эпохи. Несмотря на формальную беспартийность („Я не кадет и подробно мотивировал коллегам, почему на их предложение вступить в партию отвечаю отказом" ${ }^{\prime 19}$, к сожалению мне эти мотивы неизвестны), сочувствовал этой партии („за напускным

14 См.: В. Г. Щеглов, Высшее учебное заведение в г. Ярославле имени Демидова в первый век его образования и деятельности (6 июня 1803-1903 г.): Исторический очерк, Ярославль 1903.

15 РГИА, Ф. 733, Оп. 153, Д. 186, Лл. 105 об. 106; ИР ЦНБ, Ф. III, № 56752, Л. 2 об.

16 Там же, Л. 3.

17 Письма Ф. В. Тарановского Н. П. Павлову-Сильванскому, с. 179.

18 См.: „Юридическая библиография”, Ярославль 1907, №№ 1, 3; 1908, № 5 и др.

19 ИР ЦНБ, Ф. ІІІ, № 56752, Л. 1; там же, Л. 3. 
англоманством лучшие традиции найдете у кадетов”20) и состоял сотрудником прокадетской газеты „Северная Речь”, где напечатал две статьи о „лжеконституционалистах”: в одной из них нападал „на октябристов за блок с Союзом русского народа", а в другой - полемизировал, причем последняя статья даже „вызвала переполох среди местных октябристов" 21 .

Тарановский соглашался с Б. Кистяковским в оценке „творческих сил конституционализма” как „могучих”. Он подчеркивал, что эти силы „поведут несомненно к дальнейшим «метаюридическим» преобразованиям нашей конституции (так он оценивал Манифест 17 октября 1905 г. - С. М.) при одном само собой разумеющемся условии - незыблемости самого конституционного принципа". Идеалом Тарановскому представлялось правовое государство, основанное на двух принципах - ограниченности государственной власти и единстве между государственной властью и народом. Причем безусловным выводом из реализации этих принципов должно быть „развитие системы субъективных публичных прав” (поисками прототипов этих прав, как будет видно далее, он занимался и при изучении истории средневековых земских соборов) $)^{22}$.

Но главным делом Тарановского - наряду с учебной работой была подготовка докторской диссертации. Из писем Павлову-Сильванскому следует, что Тарановский предполагал написать ее очень быстро, рассматривая как труд обязательный, но не любимый. Вначале предполагалось написать второй том о германской юриспруденции, но затем ученый остановился на сюжетах из истории французской правовой практики. Создание книги, посвященной анализу деятельности Парижского парламента в середине XVIII в. ${ }^{23}$, было облегчено ежегодными поездками за границу, в частности, во Францию, в летнее каникулярное время. Тема диссертации была близка потребностям читавшегося в Ярославле курса государствен-

20 Там же, Л. 1.

21 Ф. В. Тарановский, Рец,: Иеллинек Г. Конституции, их изменения и преобразования, „Юридическая библиография”, СПб. 1907, № 1, с. 31.

22 Он же. Реи.: Кистяковский Б. А. Государство правовое и соичиалистическое (Вопросы философии и психологии, Кн. 85, 1906), „Юридическая библиография”, СПб. 1907, № 1, с. 32.

23 Он же. Догматика положительного государственного права во Франции при старом порядке, Юрьев 1911. 
ного права и представляла собой если не сюжетное, то идейно продолжение темы магистерской работы: там речь шла о правовой системе Германии накануне крушения абсолютизма, здесь - о французской юридической идеологии в такое же переломное время. Однако, как справедливо заметил Омельченко, „камерные” исследования Тарановского скорее предугадывали большие методологические выводы, нежели впрямую делали их ${ }^{24}$. Это, впрочем, не помешало книге быть высоко оцененной современной ей критикой ${ }^{25}$, автору была присуждена медаль М. Н. Ахматова Российской Академии наук ${ }^{26}$. Диссертация была защищена Тарановским только в 1911 г., так же как и магистерская - в Петербурге. В такой задержке сыграл свою роль новый переезд ученого: в 1908 г. он покинул Ярославль и уехал в лифляндский Юрьев (Дерпт-Тарту), где освободилась кафедра истории русского права в связи с переходом в столицу избранного в академики профессора М. А. Дьяконова. В Юрьеве Тарановский проработал девять лет.

По сравнению с Варшавой и даже Ярославлем Юрьев был чрезвычайно мал и провинциален по духу. „Его можно в 30-40 минут пройти насквозь пешком... Он живет, главным образом, университетом: во время каникул, когда студенты разъезжаются по домам, жизнь города замирает". Профессора университета делились на две группы: занимающихся наукой и не занимающихся. По воспоминаниям современника, преобладала вторая: профессора „увлекались лаун-теннисом, зимой посещали гимнастический зал, ходили друг к другу в гости, засиживались в венской кондитерской за кофе и за шахматами, некоторые занимались музыкой или театром [...]. Вообще, тонуса научной работы не было"27. Частым явлением было назначение в Юрьевский университет профессорами магистров и даже магистрантов (то есть сдавших магистерские экзамены, но не защитивших диссертации), и „многие в таком состоянии и остались”.

24 О. А. Омельченко, Указ. соч., с. 57.

25 Н. Кареев, Догма государственного права дореволюционной Франции, „Журнал Министерства народного просвещения” (ЖМНП) 1911, № 10, c. $193-235$.

26 М. М. Ковалевский, Отзыв о сочинении Тарановского Ф. В. „Догматика...", в: Сборник отчетов о премиях и наградах, присуждаемых Российской Академией Наук, Вып. VII, Отчеты за 1912 г., Пг. 1918, с. 294-303.

27 К. К. Сент-Илер, Юрьев - Воронеж, в: Пятнадиать лет ВГУ, Воронеж 1934, c. 31-33. 
Тарановский, как уже отмечалось, счастливо избежал участи „многих". После защиты диссертации он стал ординарным профессором, что давало возможность претендовать на кафедру в более престижном университете, чем Юрьевский. В 1912 г. министр народного просвещения Л. А. Кассо предложил Тарановскому перейти в Петербургский университет на кафедру энциклопедии права, вместо покинувшего университет крупнейшего юриста Л. А. Петражицкого и тем самым вновь сменить специальность. Возможному переходу, казалось, должно было способствовать и то обстоятельство, что с января 1912 г. Тарановский уже читал лекции в Петербургском университете в качестве приват-доцента, два дня еженедельно проводя в столице ${ }^{28}$. („Утомили меня поездки в Питер настолько, что никак не могу избавиться от подавленности и апатии", жаловался он Спекторскому $)^{29}$; причина этих еженедельных „маятниковых миграций” крылась, безусловно, в материальной неустроенности: к этому времени Тарановский был главой большой семьи - жена Мария Николаевна и трое детей: дочь Татьяна, сыновья Никита и Кирилл, а жалованье юрьевского профессора было ниже, чем у петербургского или московского, по тем же причинам, что и ранее, в Ярославле: контингент студентов на юридическом факультете был значительно меньше, чем в столицах. Еще в августе 1910 г. Тарановский сетовал в письме варшавянину Спекторскому: „Ваш университет отнял у нас семинаристов и существование у нас мизерное: принято всего около 70 человек на юридический факультет. Если Шварц не утвердит меня профессором на Бестужевских курсах, придется мне буквально положить зубы на полку”з30 ( Вначале выпускники семинарий могли поступать только в отдаленный Томский университет, в начале XX в. к нему добавились Варшавский и Юрьевский. По мнению И. А. Малиновского, это было связано с желанием правительства усилить православное влияние в неправославных районах империи. Но несмотря на все трудности, Тарановский ответил на предложение Кассо отказом. Формальной причиной отказа было нежелание расставаться с исторической тематикой и неготовность к занятию столь сложной кафедры, реальная же причина крылась в ином: Кассо предлагал

28 РГИА, Ф. 733, Оп. 155, Д. 352, Л. 76 об., 84 об., 85; СПб. филиал Архива РАН, Ф. 113, Оп. 3, Д. 365 , Л. 1 об.

${ }^{29}$ ИР ЦНБ, Ф. ІІІ, № 56771, Л. 2.

${ }^{30}$ ИР ЦНБ, Ф. ІІІ, № 56762, Л. 2. 
занять кафедру по назначению, а не по избранию, что сразу поставило бы Тарановского в оппозицию другим профессорам университета.

Через несколько месяцев, когда Тарановский был уже избран Советом Петербургского университета на эту, по-прежнему вакантную, кафедру, Кассо его не утвердил в должности: сыграл свою роль отказ в начале года ${ }^{31}$. А в 1913 г. Тарановскому пришлось под давлением попечителя учебного округа, которому непосредственно подчинялся университет, занять по совместительству вакантную кафедру энциклопедии права у себя в Юрьеве ${ }^{32}$.

Научная продукция Тарановского начала века распадается на две части: историко-правовую и теоретико-правовую. Обе части отвечали потребностям читавшихся профессором курсов - истории русского права и энциклопедии права. Исторические сочинения Тарановского производят впечатление глав подготовлявшегося большого труда. Они, в свою очередь, могут быть подразделены на, во-первых, труды по истории права Древней Руси и Московского государства и, во-вторых, работы по истории России XVIII в. К первым относятся обширная статья „Соборное избрание и власть великого государя в XVII столетии” (ЖМЮ 1913, № 5), энциклопедическая статья Земские соборы (Новый энциклопедический словарь Брокгауза-Ефрона, СПб., Б.г., Т. 18) $)^{33}$, а также обширный отзыв (фактически монография) о сочинении В. И. Сергеевича Древности русского права, выдвинутый на соискание премии графа Сперанского (Юрьев, 1911). Сюда же относятся рецензии на первые тома Истории русской общественной мысли Г. В. Плеханова („Былое” 1917, № 3); на сочинение Б. Д. Грекова Новгородский дом Св. Софии (ЖМЮ 1915, № 2); на труд Г. М. Бараца Критико-сравнительный анализ договоров Руси с Византией („Византийский временник” 1913, Т. ХХ, № 2-3). Сюда же примыкает обширная историографическая статья с изложением взглядов М. П. Погодина Норманская теория в истории

31 Там же, № 56776.

32 Там же, № 56783 , Л. 1 .

332 января 1914 г. Тарановский писал Спекторскому: „Пришлось писать Земские соборы для Энииклопедического словаря Брокгауза-Ефрона. Увлекся и обработал вопрос монографически: и для курса пригодится, и статья вышла, смею думать, не совсем шаблонная” (ИР ЦНБ., Ф. ІІІ, № 56786, Л. І. об.). 
русского права (Варшава 1909). Второй раздел представлен несколькими работами, в том числе двумя статьями о Наказе императрицы Екатерины II (Политическая доктрина абсолютизма в Наказе императрицы Екатерины II, в: Сборник статей по истории права в честь профессора М. Ф. Владимирского-Буданова, Киев 1904; Судьба Наказа императриць Екатеринь Второй во Франциии, ЖМЮ 1912, № 1).

Тарановский не написал никакой большой, обобщающей исторической работы, не издан полностью и читавшийся им курс истории русского права - Тарановский отдал предпочтение лекциям по энциклопедии права, вышедшим отдельным изданием в Юрьеве в 1917 г. Кроме этой книги, теоретические сюжеты поднимались ученым в ряде статей (Интерес и нравственный долг в праве, Варшава 1899; Сравнительное правоведение в коние XIX в., Варшава 1902; Историческое и методологическое взаимоотношение истории, догмы и политики права, ЖМЮ 1917, № 3), в обеих диссертациях и в многочисленных рецензиях, которые он не переставал публиковать в журналах и после отъезда из Ярославля ${ }^{34}$. Несколько особняком стоит обширная статья Тарановского Феодализм в России (Варшава 1902), написанная на основе доклада, прочитанного в Обществе истории, философии и права при Варшавском университете: в ней он поднимает и конкретно-исторические, и теоретические вопросы. Дореволюционное научное наследие Тарановского, таким образом, весомо и разнообразно. (Несмотря на неоднократно заявляемые намерения, Тарановский так и не вернулся к изучению литовско-русского права).

Много волнений в устоявшуюся, в общем, жизнь ученого внесла Первая мировая война. Очень скоро Юрьев стал прифронтовым городом, был поднят вопрос об эвакуации университета. В отличие от Университета Св. Владимира в Киеве, где такая же проблема была разрешена его эвакуацией в Саратов на 1915-1916 уч. год, в Юрьеве положение осложнилось расслоением среди профессоров, где было немало немцев. Немцы желали остаться, большинство русских уехать. Поиск места эвакуации не привел к однозначному выбору: предлагались Екатеринослав, Пермь, Ярославль. Русский по нацио-

34 См. например: Рец.: Б. А. Кистяковский, Социальные науки и право: Очерки по методологии соцчиальных наук и общей теории права, М. 1916, „Журнал Министерства юстиции” (ЖМЮ) 1917, № 2-3, с. 294-310. 
нальности, Тарановский тем не менее очень тяжело переносил саму мысль о необходимости переезда на восток России. В письме А. С. Лаппо-Данилевскому 3 февраля 1916 г. он писал: „Будучи насквозь человеком западным и нервным, я страшусь ссылки на дальний восток Европы и сидения в Перми, где заниматься наукой нельзя, учить будет некого и придется тянуть канитель истинно бюрократической видимости дела” ${ }^{35} .27$ февраля 1916 г. Тарановский призвал на заседании Совета университета отсрочить эвакуацию в Пермь (именно этот город в итоге стал рассматриваться как наиболее вероятное место переезда), мотивируя своё мнение, во-первых, ненужностью краткосрочной эвакуации, так как через год ситуация на фронте безусловно изменится к лучшему, и во-вторых, плачевным примером Казанского университета, недобирающего студентов ${ }^{36}$. Речь Тарановского (наряду с выступлениями некоторых его коллег) возымела действие, эвакуация была отложена. (В Перми в том же 1916 г. был открыт новый университет, вполне удовлетворительно функционировавший. Эвакуация же Юрьевского университета состоялась только в июле - сентябре 1918 г., когда город был занят немцами и значительная часть оборудования поэтому осталась в Дерпте ${ }^{37}$ ).

В том же 1916 г. Тарановский оформил себе прикомандирование на год к Академии наук, что позволило ему, оставаясь формально профессором университета, лекций в нем не читать, а жить в Петрограде и работать в архивах, так как целью прикомандирования было подготовить научное издание Устава Благочиния Екатерины II. Временное изменение статуса Тарановского произошло при помощи Лаппо-Данилевского. В феврале 1916 г. Тарановский писал ему в Петроград: „С августа - сентября я свободен, и мне нужно засесть за новую систематическую работу. Как я не размышлял, все же нахожу для себя подходящим сосредоточиться на истории русских политических учений до конца XVIII в. С этой стороны и так как

35 СПбфАРАН, Ф. 113, Оп. 3, Д. 365, Л. 7 об.

${ }^{36}$ Речь профессора Ф. В. Тарановского, произнесенная в заседании Совета Императорского Юрьевского Университета 27 февраля 1916 г. по вопросу об эвакуации Юрьевского университета, „Ученые записки Императорского Юрьевского университета" 1916, № 3, с. 1-840.

37 См.: К. Сент-Илер, К истории Воронежского университета: История последних дней русского Юрьевского университета, Воронеж Б. г. 
я писал о наказе Екатерины II, для меня представляет большой интерес Устав Благочиния, как памятник просвещенного абсолютизма, то есть того политического течения, которое знакомо мне более других. Однако и Табель рангах также для меня интересна, как конституционная хартия бюрократии, мимо юридической и политической идеологии которой мне все равно нельзя будет пройти. Поэтому выбор того или другого из указанных памятников для поручения мне подготовительных работ по его изданию всецело представляю на Ваше усмотрение. Для меня в конечном счете все равно, с какого конца войти в систематическую работу, лишь бы войти в нее”38. Тарановский был полон планов. „Считаю себя обязанным разрешиться от бремени разных продуманных тем, замечал он в письме Спекторскому. По окончании учебника энциклопедии (месяц работы) выпущу ряд этюдов по истории русского права"39. В итоге был выбран Устав Благочиния, но работа над ним осталась неоконченной.

События Февральской революции оказали сильнейшее морально-психологическое воздействие на Тарановского. Несмотря на вторичное избрание в апреле профессором Петроградского университета $^{40}$, Тарановский в конце месяца вслед за ранее эвакуированной семьей уехал на Украину, где под Харьковом жили его родственники. „Нервы до того у меня издерганы, что не в состоянии теперь жить в одиночестве в Петрограде [...]. - писал он Лаппо-Данилевскому Должен непременно удалиться и от фронта, и от Петрограда, чтобы привести себя в порядок и восстановить полностью свою работоспособность" ${ }^{\prime 1}$. Тарановский, конечно, не мог предвидеть события осени 1917 г., поэтому собирался возвращаться в Петроград для продолжения работы над Уставом. Но в столицу он, судя по всему, больше не вернулся.

Закончен был важный этап жизни и творческой деятельности Тарановского. Его имя прочно вошло в круг виднейших отечественных историков-юристов, он приобрел известность в академической среде и популярность как критик.

\footnotetext{
38 СПбфАРАН, Ф. ИЗ, Оп. 3, Д. 365, Лл. 7-7 об.

39 ИР ЦНБ, Ф. III, № 56800, Л. 4.

40 РГИА, Ф. 740, Оп. 19, Д. 5, Лл. 47-47 об., 50.

41 СПбфАРАН, Ф ИЗ, Оп. 3, Д. 365, Лл. 9-9 об.
} 
К сожалению, состояние источников не позволяет подробно проследить жизнь Тарановского в 1917-1920-х гг. 1918-1919 учебный год он провел преимущественно в Екатеринославе, где был избран деканом юридического факультета в только что открытом университете. Он занял там кафедру истории русского права, но предполагал перейти в Харьков на планировавшуюся там кафедру истории западно-русского права ${ }^{42}$. В это время в Киеве среди местной интеллигенции рождается идея создания украинской академии. Одним из ее основателей и первым президентом был В. И. Вернадский. Вероятно, именно он привлек в академию и Тарановского. 3-5 октября 1918 г. Тарановский находился в Киеве по вызову министра просвещения гетманского правительства Н. П. Василенко для учреждения академии. Вначале Тарановский занял кафедру сравнительной истории права, позднее он был избран главой социально-экономического отдела. Однако сотрудничество его с академией ограничилось в основном перепиской и опубликованием позже нескольких работ в академических изданиях. (Из-за петлюровского наступления он не смог попасть в Киев уже на организационное собрание 26 ноября 1918 г. $)^{43}$.

Но, как ни парадоксально, это время оказалось достаточно плодотворным в научном отношении. Тарановский вернулся к когда-то затронутому им сюжету и написал ряд объемных статей по частным вопросам истории польского права XVII в. ${ }^{44}$ Такие темы объяснялись, несомненно, оторванностью Тарановского от источников.

В июле 1919 г. ученый принял предложение войти в состав Особого Агитационного Отряда Отдела Пропаганды Особого Совеща-

42 ИР ЦНБ, Ф. 1, № 27014, Л. 1.

43 Там же, № 27018, Лл. 1-6 об.

44 Ф. Тарановський, Догматика державного права Речи Посполітої XVII в. в праці Христофора Гарткноха, в: Записки сочіяльно-економічного відділу УАН (ЗСЕВ), Київ 1926, Т. II-III, с. 69-123; Він же, Статистичні описи Польщі Кромера й Старовольского та їх значения для утворення догматики польского державного права в XVII в., ЗСЕВ, Київ 1926, Т. IV, с. 1-39; Він же, Літературна полеміка 60-х років XVII віку про мету Польскої держави, як привід до відокремлення догматично-юридичного виучування политичного устрою Речи Посполітої, ЗСЕВ, Київ 1927, Т. V-VI, с. 1-25; Він же, Перший систематичний виклад догми державного права Речи Посполітої в другій половині XVII в. в трактаті Хвальковського, ЗСЕВ, Київ 1927, Т. V-VI, с. 26-60. 
ния при Главнокомандующем Вооруженными Силами на Юге России. С отрядом он ездил на Кавказ и в Крым, где организовал курсы политического просвещения. В это же время он был наконец избран на искомую кафедру в Харькове, но, судя по письмам, колебался между поездкой в холодный зимний Харьков и переходом в Таврический университет в Симферополе ${ }^{45}$.

Сотрудничество Тарановского с белыми, разруха в стране и неустроенность быта неминуемо вели его к эмиграции. Весной 1920 г. он оказался в Королевстве Сербов, Хорватов и Словенцев среди почти семидесяти тысяч русских, эмигрировавших туда в это время. Далеко не столичным предстал Белград перед эмигрантами из России. Внешне это был „очень провинциальный город с ярко выраженными следами недавней войны: на зданиях были видны знаки от австрийских гранат и снарядов [...]. Каких-либо видных, больших зданий было мало, да и те обшарпанные. Большинство домов низенькие одноэтажные зданьица, крытые черепицей. Деревьев мало, в основном акация. Покрытие на улицах очень плохое, разбитое, за исключением двух-трех главных улиц, мощенных деревом. Все спалено солнцем, прокурено, запорошено и очень напоминало [...] Екатеринослав, каким он бывает в начале осени после сухого, бездождевого лета" ${ }^{\natural 6}$. В этом городе Тарановскому предстояло проработать шестнадцать лет. В отличие от других стран, в КСХС „свидетельства и дипломы об образовании русских специалистов, полученные в России, военные звания, присужденные до Февральской революции 1917 г. и научные звания русских ученых считались имеющими законную силу”. В 20-е гг. только в Белградском университете работало 45 русских профессоров ${ }^{47}$. В Белградском университете обучалось 625 студентов из России, в Загребе - 285, в Любляне - 137 и на юридическом факультете в Суботице - 40. Кроме него, как уже отмечалось, в КСХС приехали историки права М. Н. Ясинский и Г. В. Демченко; вместе с Тарановским в Белграде оказался и его

45 ИР ЦНБ, Ф. 1, № 27019, Л. 1 - 1 об.

46 Д. Дорошенко, Моп спомини про недавне - минуле (1914-1920), Вин. 2, Мюнхен 1969, с. 471.

47 См.: В. А. Тесемников, Деятельность Русского научного института в Белграде (1928-1941), в: Развитие общественной мысли в странах Центральной и Юго-Восточной Европы, М. 1991, с. 174; Он же, Русские в учебных заведениях Югославии (1921-1941), в: Роль русского зарубежья в сохранении и развитии отечественной культуры, М. 1993, с. 29-33. 
друг, последний ректор Университета Св. Владимира в Киеве Е. В. Спекторский.

Вот когда пригодилось изученное под руководством Леонтовича югославянское право - Тарановский сразу же был избран профессором пустовавшей до этого много лет кафедры славянских законодательств Белградского университета. Уже в апреле 1920 г. в Белграде было создано Общество русских ученых КСХС во главе со Спекторским; товарищем (заместителем) председателя стал Тарановский ${ }^{48}$. В 1928 г. был открыт Русский научный институт в Белграде - наиболее известное российское культурно-образовательное учреждение в Югославии. Первым председателем института стал Спекторский, а после его переезда в Любляну на эту должность избрали Тарановского. Он занимал пост председателя с 1930 по 1936 г. и немало сделал для подъема престижа института. Уже в 1933 г. в Белграде был открыт Русский Дом имени Императора Николая II, где разместился институт и другие культурно-просветительские учреждения. Выступивший на открытии Дома Тарановский подчеркнул важное значение института для развития русской науки в эмиграции.

С 1928 по 1935 г. Тарановский тридцать раз выступал с докладами на заседаниях института. Тематика их была разнообразна: „Б. Н. Чичерин как историк русского права”, „С. М. Соловьев и история русского права”, „Общее значение великих реформ императора Александра II в истории русской государственности” и др. В 1931 и 1932 гг. ученый вел в институте семинарий по истории русского права земского периода. Деятельность Тарановского не ограничивалась только столицей страны - он читал публичные лекции в Дубровнике, Загребе, Самборе и Суботице ${ }^{49}$.

За время своего существования (1928-1941 гг.) институт выпустил 17 томов записок, многие материалы которых не потеряли научной ценности до сих пор; в Белград приезжали по приглашениям института представители русской диаспоры в Европе из Парижа, Софии, Праги, Берлина и, несмотря на низкий интеллектуальный уровень основных эмигрантских кругов в Югославии (большинство

48 См.: Труды русских ученых за границей, Берлин 1923, Т. II, с. 279. Российская эмиграция в Туричи, Юго-Восточной и Центральной Европе 20-х годов (гражданские беженцы, армия, учебные заведения), М. 1994, с. 90-91.

49 ЗРНИ, Белград 1939, Вып. 14, с. 1-27. 
эмигрантов были бывшие военные, казаки и т.п. $\left.{ }^{50}\right)$, лекции пользовались большой популярностью.

По свидетельству известного философа В. Зеньковского, также эмигрировавшего в Югославию, в Земуне, пригороде Белграда, где жил Тарановский, им был создан религиозно-философский кружок, активно функционировавший. Как вспоминал Зеньковский, „работали мы дружно, все прежнее или забылось, или отодвинулось ",51.

В Югославии Тарановский не прекратил активной научной деятельности - за пятнадцать лет эмиграции он опубликовал несколько десятков книг, статей и рецензий. Во-первых, он продолжил разработку сюжетов истории русского государства и права (Обеспечение прав служилого землевладения в сословно-монархическом строе Московского государства, Львов 1925; Элементы основных законов в Уложении ияаря Алексея Михайловича. К истории политического строя удельной Руси, Харбин 1928); во-вторых, много работал по истории славянского, а особенно - это понятно - сербского права (Увод у историју словенских права, Београд 1922; 2-е изд. - 1933; Стогодишњица научног рада Мађејовског на истории словенских права, в: Летопис Матище Српске, Нови Сад 1932, Кн. 331; Историја српског права у Немањиђкој држави, I део: Историја државног права, Београд 1931; 2 део: Историја кривичног права, Београд 1931;3-4 део: Историја грађанског права. Историја судског уређења и поступка, Београд 1935); в-третьих, им было опубликовано несколько принципиальных теоретических статей философско-юридического содержания (Периодизачия в истории права, в: Труды русских ученых за границей, Берлин 1923, Т. II; Предмет и задача т. н. внешней истории права, ЗРНИ, Белград 1931, Вып. I и др.). Кроме того, был переиздан с дополнениями учебник Эничиклопедия права (Берлин 1923). В сентябре 1928 г. Тарановский был одним из организаторов IV съезда Русских академических организаций за границей, проходившего в Белграде; подготовил для выступления на пленарном заседании доклад о славянстве как предмете историко-юридического изучения (Tpydbl IV cъезда РАОЗГ, Белград 1929 , ч. I). Научная деятельность Тарановского не оказалась незаме-

50 M. Raeff, Russia Abroad: A Cultural History of the Russian Emigration, 1919-1939, N.-Y.-Oxford 1990, p. 65-66.

51 В. Зеньковский, Мои встречи с выдающимися людьми, в: Записки Русской академической группы в США, Нью-Йорк 1994, Т. XXVI, с. 53. 
ченной в Югославии - он был избран членом Сербской Академии наук $^{52}$.

Еще в мае 1916 г. он, откликаясь на смерть крупного историка права М. Ф. Владимирского-Буданова, размышлял в письме Спекторскому: „Старики уходят в могилу, и наше поколение становится представителем состояния русской науки. Это не воображение, не желание, а факт. Среди этого поколения на разных Палиенок и даже Котляревских (юристы начала века - С. М.) не возложу моих надежд". Поневоле остается тесный круг, куда я отношу Вас, Богдана Кистяковского и некоторых других, преимущественно историков, юристы очень слабы. Вот и варишься в приятельском соку... Сознание ответственности за научную работу нашего поколения глубоко проникает в душу"53. Кистяковский умер в 1919 г., час Тарановского пробил 23 января 1936 г.

В выпущенном несколько позже номере записок Русского научного института раздел, посвященный памяти Тарановского, открывала статья Спекторского ${ }^{54}$ - последнего из очерченного его другом „приятельского круга,

Методология Ф. В. Тарановского до сих пор совершенно не привлекала внимания исследователей, в то время как сам ученый придавал этому аспекту своего творчества особое значение. В 1917 г. Тарановский заметил, что „философскому мышлению, особенно в приложении его к наукам об обществе, праве и государстве, не везет как-то у нас на Руси. Мало в нем строгой дисциплины ума и подлинной научности" 56 . В этой связи тем более важным и интересным становится анализ методологии трудов историка.

Как показывает изучение работ Тарановского, основой его философии истории и права был позитивизм - общая методология киевской школы. Однако поскольку Тарановский работал уже в начале

52 В. А. Тесемников, Российская эмиграцияя.., с. 132.

53 ИР ЦНБ, Ф. ІІІ, № 56800, Лл. 3-3 об.

54 Е. В. Спекторский, Указ. соч.

55 Тарановский был достаточно известен за рубежом. См. например: К. Kadlec, Introduction a I'étude comparative de I 'histoire du droit public des peuples slaves, Paris 1933; J.-J. Gapanovitch, Historiographie russe hors de la Russie, в: Introduction a I'histoire de la Russie, Paris 1946, p. 198.

56 Ф. В. Тарановский Рец., Кистяковский В. А. Социальные науки и право, ЖМЮ 1917, № 2-3, с. 308-309. 
XX в., то позитивизм его был не классический, в духе О. Конта, a реформированный. В отличие от основоположника этой философской системы, Тарановский в начале своей научной деятельности не следовал теории факторов, все из которых были бы равнозначны в историческом процессе; ученый выделял какой-то один, преобладающий фактор. В эпоху широкого увлечения экономизмом этим фактором стала экономика общества, его хозяйственное состояние. Так, в одной из ранних статей Феодализм в России Тарановский, предлагая для создания более адекватной картины явления дополнить юридическую концепцию Н. П. Павлова-Сильванского результатами изучения экономической стороны феодальных отношений („,только экономическое обоснование дает поднятому вопросу солидное и непоколебимое разрешение" ${ }^{97}$ ), тем не менее подчеркивал, что и „При экономическом изучении истории юридизм не устраняется. Экономические факторы - продолжал ученый - это почва, на которой вырастают политико-правовые учреждения; их следует поэтому объяснять экономически, но конструировать можно их только юридически"

Четырьмя годами позже, в 1906 г., при начале курса лекций в Демидовском юридическом лицее он уверенно постулировал: „Без изучения экономического и социального быта совершенно невозможно не только изучение установления системы, но простое понимание отдельных явлений, норм и институтов права,59.

Эта точка зрения проводилась Тарановским и при анализе некоторых конкретно-исторических явлений. В 1915 г. в рецензии на книгу Б. Д. Грекова Тарановский подчеркивал, что вся административная и даже политическая организация Московского государства XVI и XVII вв. представляет собой только „надстройку над замкнутыми частновладельческими отчинами, которые составляли основу всего общественного уклада", причем историк выражал сожаление,

57 Ф. В. Тарановский, Феодализм в России, Варшава 1902, с. 30. Ученый подчеркивал, что „учение об обществе приобрело особенную продуктивность в своих выводах с тех пор, как в основу объяснения социального развития было положено изучение экономических факторов, как производящих причин первого порядка" (Там же, с. 11).

58 Там же, с. 38, Прим. 1.

59 Ф. В. Тарановский, Историческое и методологическое взаимоотношение истории, догмы и политики права, ЖМЮ 1907, № 3, с. 167. 
что Греков начал исследование сюжета с вопросов юридического управления вотчиной, поскольку оно „предстало бы перед нами рельефнее, если бы [...] было дано на фоне предварительного изображения ее хозяйства и тягла" ${ }^{60}$. В рецензии на книгу В. И. Сергеевича Древности русского права Тарановский критикует желание автора оставаться „на точке зрения юридической и политической” при анализе причин изменения государственных интересов крупных землевладельцев (бояр) в период образования единого русского государства. Тарановский считал, что эти причины „выясняются в порядке изучения хозяйственного развития и объединения волостей, вошедших затем в единую державу московских государей"61. Наконец, в отзыве о первых томах плехановской Истории русской общественной мысли Тарановский, заявляя, что „можно и [...] следует возражать против материализма, как единой основы и исключительной системы социальной философии”, подчеркивал, что „в области причинного, генетического объяснения социальных явлений экономический материализм оказывается наиболее плодотворной и потому наиболее ценной рабочей гипотезой"б2.

В 1917 г. вышел в свет Учебник энщииклопедии права Тарановского. В нем немало места уделено вопросам экономического воздействия на правовые системы. Это касается, прежде всего, определения государства. К традиционному для юриспруденции того времени определению государства как союза людей, „живущих на определенной территории и подчиненных единой политической власти"63, Тарановский добавил новую тогда взаимосвязь между государством и обществом (М. Ф. Владимирский-Буданов, например, считал общество частью государства). Он полагал, что „для государства” целесообразно оставлять только „организацию властвования”, которая создается „на почве общественных (социальных) отношений”. Та или иная структура общества („социальная дифференциация”) зависит, по мнению Тарановского, от хозяйственных потребностей

60 Ф. В. Тарановский Рец., Греков В. Д. Новгородский дом Св. Софии..., ЖМЮ 1915, № 2, с. 332, 334.

61 Ф. В. Тарановский, Отзыв о сочинении В. И. Сергеевича „Древности русского права...", Юрьев 1911, с. 21.

62 Ф. В. Тарановский Рец., Плеханов Г. В. История русской общественной мысли, Тт. 1-2, „Былое” № 3, с. 266.

63 Ф. В. Тарановский, Учебник энцииклопедии права, Юрьев 1917, с. 333. 
„в обеспечении материального существования индивидов ${ }^{\text {”4 }}$. Далее он еще раз подчеркивает - „накопление имущественных благ ведет к расчленению общества на отдельные общественные классы” ${ }^{\prime 2}$. При характеристике трудов экономистов, на которые ученый опирался, разрабатывая свою теорию социальной стратификации, теперь значился, наряду с М. Ковалевским и К. Лампрехтом, и К. Маркс. Причем именно Марксу, по мнению Тарановского, принадлежало в середине XIX в. первое место в разработке учения об обществе ${ }^{66}$.

Однако эти высокие оценки экономизма оказались последними в творчестве Тарановского. Уже в том же учебнике, давая высокую оценку позитивизму („он точно определил объект познания, указал, какая положительная цель доступна человеку в области мысли и установил те приемы, помощью которых эта цель может быть достигнута"67), ученый, наряду с „экономическим началом производства и распределения материальных благ", отметил еще два фактора объединения индивидов в общественные группы - „физиологическое начало кровного родства", как наиболее раннее по времени действия, и ,духовное начало нравственного и умственного развития" ${ }^{\prime 6}$. Решительный поворот историка к классической теории факторов произошел после революции и гражданской войны, когда он оказался в эмиграции в Югославии. Скептически оценивая политическую деятельность большевиков, Тарановский объявил любой монистический подход субъективным и уже в 1923 г., говоря о развитии права, ученый в качестве влияющих на него факторов называл, наряду с экономическим, военный и понимаемый широко духовный (религию, мораль, психологические и национальные особенности $)^{69}$. Через десять лет Тарановский уже безусловно отмечал правоту О. Конта и призывал к учету всей множественности факторов, которые в итоге должны образовать консенсус, влияющий на общественное развитие. К перечислявшимся ранее трем факторам он, видимо, под влиянием эмоциональной теории права Л. И. Петражицкого, добавил „социально-психологическое” воздействие как важный

64 Там же, с. 369.

65 Там же, с. 370.

66 Там же, с. 369.

67 Там же, с. 38.

68 Там же, с. 369-370.

69 Ф. Тарановски, Увод у историју словенских права, Београд 1922, с. 49. 
фактор, объединяющий три других ${ }^{70}$. Так же как и ранее, теоретические выводы ученого нашли отражение в конкретно-исторических работах. В Истории сербского права он, сочувственно отзываясь о теории В. О. Ключевского о происхождении сословий на основе политического и экономического начал, предложил свой комплекс факторов. По мнению Тарановского, социальная и правовая дифференциация прошлого базировалась на выделявшихся им ранее физиологическом, экономическом и духовном началах ${ }^{71}$.

Таким образом, начав как сторонник экономизма, к концу своей творческой деятельности, Тарановский окончательно перешел на плюралистские позиции классической теории факторов, проделав эволюцию, обратную развитию взглядов многих его современников.

Вторым, после теории факторов, основанием позитивизма, как известно, является эволюционная теория Г. Спенсера. Тарановский был безусловным и стойким приверженцем эволюционизма на протяжении всей творческой жизни. Он заявлял, что „верховное начало истории - идея движения" ${ }^{72}$. В отличие от „чистых” историков, Тарановский позаимствовал идею эволюционного развития не только у Спенсера, но и у Иеринга. Во всяком случае, он подчеркивал даже в 1923 г., что для историков права воззрения Иеринга „до сих пор сохранили значение руководящих начал"

Однако Тарановскому было не близко монистически идеалистическое содержание эволюционной теории исторической школы (,спиритуалистический дух ${ }^{\text {,74 }}$ ), поэтому заимствуя саму идею эволюции, он наполнял ее новым содержанием. (Стоит подчеркнуть, что воззрения основоположников исторической школы права Савиньи и Пухты представлялись Тарановскому в значительной степени устаревшими. Однако он пытался некоторые моменты их методологии объяснять с точки зрения современной ему науки. Так, он „обновил” концепцию национального права, разделявшуюся Влади-

70 То же, 2е изд., Београд 1933, с. 68.

71 Т. Тарановски, Историја српског права у Немањиђкој држави, Београд 1931, 1 део, с. 2.

72 Ф. В. Тарановский, Отзыв о сочинении В. И. Сергеевича..,, с. 87.

73 Ф. В. Тарановский, Энциклопедия права, 2-е изд., Берлин 1923, с. 259.

74 В письме Е. В. Спекторскому он писал, что только позитивизм дает рабочую, гипотезу. „Дает ли ее критический идеализм? - Нет” (ИР ЦНБ, ф. ІІІ, К. 56787 , Л. 1 об.). 
мирским-Будановым. Он отмечал, что „национальное право древности является ничем иным, как сравнительной конструкцией, построенной историком из дробного партикуляристического материала. Конструированные таким образом институты национального права нигде и никогда не действовали во всей их полноте, ибо везде были свои местные особенности юридического быта. Тем не менее такие конструкции являются вполне уместными с научной точки зрения, так как в них ярко выражены те элементы действительной общности правового развития, которые в дальнейшем привели к образованию единой системы национального права". (Ф. В. Тарановский, Энииклопедия права, Берлин 1923, с. 266). Наиболее последовательно эта идея в творчестве Тарановского воплощена в учении о периодизации истории права.

Первоначально интерес к периодизации истории государства и права был вызван у ученого потребностями читавшегося им на юридических факультетах разных вузов курса истории русского права. Первыми подступами к разработке теории периодизации были замечания, содержащиеся во вступительной лекции при начале курса в Демидовском юридическом лицее в Ярославле в 1906 г. Здесь он, заметив, что „цельность и законченность исторического периода определяется для юриста непрекращающейся возможностью сводить совокупность разрозненных правовых явлений, норм и институтов к нескольким руководящим юридическим принципам, по которым может быть построена единая, исключающая внутренние противоречия система права”, заявил: „Моменты, когда такая возможность прекращается, [...] неминуемо признаются юристом за исходную точку новой правовой системы”. Тарановский, во многом справедливо, полагал, что юристу легче выделять периоды в истории, так как общество и экономика меняются медленнее и изменения в них не так четко оформлены, как в праве. Поэтому логически правильным выглядит вывод Тарановского о том, что „отдельные периоды истории права - установленные для прошедшего законченные системы права" 75 .

Полностью концепция теории периодизации истории права была развернута Тарановским в одноименной статье, вышедшей в 1923 г. В этой работе в идею эволюционное ${ }^{\mathrm{TM}}$ ученый внес понятие преры-

75 Ф. В. Тарановский, Историческое и методологическое..., с. 167. 
вистости процесса, так как в истории происходит множество фактов (,малых изменений”), между которыми существуют промежутки. „,Установив показательные моменты и констатировав таким образом наличность эволюционных изменений, историк по данным прерывистого наблюдения восстанавливает ход непрерывного развития подчеркивал Тарановский - Показательные моменты отделены как бы пробелами в ходе развития, восполняются всеми данными о быте соответствующего времени, какие только историку удастся добыть из источников. Он воссоздает, таким образом, возможно полную картину жизни того времени"76. В процессе реконструкции, полагал Тарановский, объективно выделяются две стороны жизни общества - настоящее и подготовление будущего. Вторая составляющая важнее первой, так как позволяет компенсировать отсутствие положительных сведений о каком-либо периоде, выделить тем самым его характерные черты и логически завершить его. Однако дискретность исторического процесса не могла бы в концепции Тарановского сочетаться с плавным, эволюционным течением, если бы не выдвинутая им безусловная необходимость установления причинно-следственных связей между периодами и их взаимообусловленность. Именно эти характеристики позволяют Тарановскому делать вывод об эволюционном принципе развития истории, причем основной особенностью общественной эволюции оказывается как раз принцип причинности, а сама эволюция - несмотря на столь многочисленные высказывания о роли экономики - мыслится как „созидание и накопление культурных ценностей” (впрочем, у Тарановского в данном случае речь шла об эволюции правовых принципов норм) $)^{77}$.

Наконец, завершающим штрихом в концепции периодизации истории права выступает у Тарановского относительная нестабильность периодов. В духе времени заявляя, что „историческое изучение, в конце концов, есть ничто иное, как отыскание в прошлом корней и объяснения настоящего”, и что „только имея ввиду современное состояние, мы можем учесть, что в прошлом было динамически действенно и что значения не имело", ученый полагал, что любая периодизация будет меняться с изменением правовых принципов современности ${ }^{78}$.

76 Ф. В. Тарановский, Периодизаџия в истории права, в: Труды русских ученых за гранищей, Берлин 1923, Т. II, с. 205.

77 Там же.

78 Там же, с. 209. 
Таким образом, под воздействием революционных событий в обществе (возможно, и в естествознании, поскольку его идея прерывности близка принципам построения квантовой теории света) Тарановский выдвинул комплексную теорию периодизации историко-правового процесса, объединив позитивистскую идею эволюции с собственной концепцией прерывистости.

Важную роль в методологии Тарановского играла и позитивистская идея закономерности и познаваемости исторического процесса. Историк полагал, что предметом познания может быть только то, что „объективно и реально существует”. Считая, что „объективно и реально" существуют не идеи, но отдельные явления, он и признавал их единственным объектом познания. Явления вступают в соотношения, которые представляют „однообразие, повторяющееся с объективной необходимостью”. Именно это „необходимое однообразие в отношениях между явлениями" и называется у Тарановского законами „этих явлений”. Вслед за Контом он делил законы на статические (законы сосуществования) и динамические (законы последовательности). Причем ,раскрытие законов явлений составляет единственную положительную цель человеческого знания”, а ,знание законов дает нам возможность предвидеть явления и, следовательно, приспособлять их для наших практических целей",79. Столь уверенное присоединение к контианской идее закономерности объясняет резкую отповедь, данную Тарановским Б. А. Кистяковскому. „Суждение автора - писал Тарановский - что «никаких законов развития не может быть», представляется нам неубедительным и [...] голословным" ${ }^{\prime 20}$.

Однако в эмиграции взгляды Тарановского несколько изменились. Более того, один из разделов второго издания учебника энциклопедии права был дополнен не просто объективистско-отстраненным, но вполне сочувственным изложением воззрений неоконтианца Г. Риккерта и интуитивиста А. Бергсона. Не отрицая приемлемости и ценности позитивизма, ученый предложил устра-

79 Ф. В. Тарановский, Учебник энияиклопедии права, с. 39.

80 Ф. В. Тарановский Рец., Кистяковский Б. А. Социильные науки..., с. 304. Десятью годами ранее он, разбирая книгу Спекторского, подчеркнул, что „общий вывод грешит нелишним [...] скептицизмом в смысле признания неприменимости теории познания к общественным наукам" (Рец.: Е. В. Спекторский, Очерки по философии общзественных наук, Вып. I, „Юридическая библиография”, Ярославль 1907, № 3, с. 6). 
нить „односторонность прямолинейного позитивизма, как некогда сам позитивизм устранял односторонность идеалистической философии". В этой связи причинно-следственные связи, предлагаемые контианской картиной мира для установления ступеней развития, оказывались недостаточными; нужна была еще „телеологическая оценка”, то есть „трансцендентальное суждение” о тех ценностях, которые создаются в истории и составляют содержание теперь уже не экономической стороны истории, а культурной. Наивысшими ценностями в градации Тарановского оказывались моральные, затем шли интеллектуальные и материальные. Но, тем не менее, несмотря на эти идеалистические экскурсы, окончательного разрыва с позитивистской парадигмой истории не произошло. Неоконтианские фразы были скорее данью политической обстановке, когда неприятие большевистского режима перерастало в неприятие экономизма, а затем на словах - и позитивизма вообще. Реально же воззрения Тарановского, особенно в конкретно-исторических исследованиях, оставались в рамках позитивизма. В том же учебнике он заявлял, что „обычный и вместе с тем самый существенный труд историка вообее и историка права, в частности, заключается прежде всего в том, чтобы тщательно и точно изучать факты... Наблюдение составляет основу исторического познания"

Итак, Тарановский исповедовал все составляющие позитивистской парадигмы. Приступив к изучению общества в начале XX в., он, однако, не мог не подвергнуться воздействию новых методологических концепций, в особенности, экономизма (и возможно, новаций в естественных науках). Отсюда обратная эволюция от выделения экономического фактора к. классическому варианту теории факторов и попытка совмещения эволюционизма с теорией прерывистости.

Из приверженности позитивистской методологии с неизбежностью вытекала приверженность сравнительно-историческому методу исследования. Тарановский был, пожалуй, одним из первых авторов, показавших именно неизбежность, а не только возможность использования этого метода для сторонников позитивистского подхода в истории права. Позитивизм, как известно, поставил общественные науки вровень с естественными по методам исследования. Одним из результатов этого явилось рождение прикладной по своим задачам

81 Ф. В. Тарановский, Энииклопедия права, с. 260-262. 
науки об обществе - социологии. Тарановский при обосновании необходимости сравнительно-исторического метода пользовался именно социологическим понятийным аппаратом. Так как основным приемом исследования позитивизма является „наблюдение явлений”, а эксперименты в общественных науках затруднительны, то роль эксперимента выполняет сравнение, то есть „наблюдение явлений в разнообразных объективно данных сочетаниях условий, не поддающихся [...] произвольному изменению" ${ }^{\text {". }}$. Только сравнение „дает возможность установления последовательности исторических филиаций” - полагал ученый ${ }^{83}$. Отсюда и закономерный для Тарановского вывод: „Позитивный исторический метод изучения права становится поневоле методом сравнительно-историческим" 84 .

Посмотрим более подробно, как реализовывались охарактеризованные методологические принципы в конкретно-исторических исследованиях.

Тарановский, как уже отмечалось, начал свою научную деятельность со специализации по кафедре истории русского трава, вначале как автор медального сочинения, а затем как профессорский стипендиат. Однако обстоятельства его научной и преподавательской карьеры сложились неблагоприятно для систематических занятий избранной им первоначально специальностью - интересы читавшихся им теоретических курсов побуждали его уделять внимание проблемам энциклопедии права, в то время как исторические работы появлялись хоть и регулярно, но с большими временными промежутками. Наиболее интересны и важны работы Тарановского по истории средневековой Руси - так называемых удельно-вечевого и Московского периодов, особенно разработка им теории феодализма.

Тарановский, по собственному признанию, заинтересовался вопросом о феодализме еще на студенческой скамье, в частности, при исследовании судеб магдебургского права в украинских землях. „Параллельное изучение восточно-русского права наводило меня на то, что и в последнем имелись черты феодализма, писал он Павлову-Сильванскому. Это вызывало у меня споры с моим учителем

82 Ф. В. Тарановский, Историческое и методологическое..., с. 163.

83 Ф. В. Тарановский, Сравнительное правоведение в коние XIX в., Варшава 1902 , c. 2 .

${ }^{84}$ Ф. В. Тарановский, Энциклопедия права, с. 263. 
проф. Леонтовичем, который решительно отрицает феодализм как в западной, так и в восточной Руси" 85 . В 1900-1901 гг. Тарановский специально изучал историю феодализма в Гейдельберге. Не случаен поэтому тот неподдельный интерес, с которым Тарановский встретил появление работ Павлова-Сильванского, посвященных проблемам феодализма в России в сравнении с Западной Европой. Тарановский вступил в переписку с петербургским исследователем. В итоге, в марте 1902 г. в юридическом отделении Общества истории, филологии и права при Варшавском университете Тарановский выступил с большим докладом, опубликованным тогда же под названием Феодализм в России.

Доклад Тарановского не стал простым изложением концепции Павлова-Сильванского: признав, что она представляется ему достаточно убедительной, согласившись с определением феодализма как „дробления власти” в удельный период, Тарановский, однако, выдвинул ряд тезисов, дополняющих и развивающих идеи предшественника. По мнению Тарановского, несмотря на значимость объяснения Павловым-Сильванским многих „отношений и институтов древней русской жизни" (закладничество, иммунитет, вассальная служба бояр), Павлов-Сильванский не смог доказать исторического существования феодализма на Руси, поскольку изучал только юридическую сторону явления, дав, таким образом, лишь „скелет” описанных им отношений. Однако „никакой живой организм не может состоять из одного скелета, - остроумно заметил Тарановский. - Следовало облечь скелет в плоть и насытить его кровью. Такое полное воплощение может дать политическому учреждению только изучение экономической почвы, его питающей"86. (Как уже отмечалось, Феодализм в России написан как раз в период увлечения экономизмом).

85 Письма Ф. В. Тарановского Н. П. Павлову-Снльванскому, с. 177.

86 Ф. В. Тарановский, Феодализм в России, Варшава 1902, с. 27, 29, 30. Значительно позднее историк подчеркивал, что в читавшихся им университетских курсах истории русского права он всегда выделял, в отличие от большинства коллег, особый удельный период в истории русского права (Ф. В. Тарановский, Элементы основных законов в Уложении царя Алексея Михайловича. К истории политического строя удельной Руси, Харбин 1928, с. 66). См. также: Н. Е. Эсперов, Указ. соч. 
Итак, какие же конкретно моменты экономической истории должны были быть изучены в первую очередь для прояснения вопроса о русском феодализме? Тарановский давал совершенно ясный ответ на этот вопрос: „В деле экономического исследования наиболее видное место должно быть отведено изучению вотчинного хозяйства и управления, как того фундамента, на котором повсюду созидался феодализм. Нет феодализма без феодалов, но нет феодалов без вотчины, самостоятельной в хозяйственном и административно-политическом отношении”. Кроме того, „выяснение вотчинного хозяйства и управления прольет свет на крайне важное для феодализма начало сословности" ${ }^{\prime 7}$. Последнее замечание было явно направлено против концепции М. Ф. Владимирского-Буданова - В. И. Сергеевича о бессословном характере Московского государства ${ }^{88}$.

Тарановский предложил использовать два метода исследования экономического содержания феодализма. Оба эти метода были имманентными частями методологии киевской школы историков. Это, во-первых, метод „областности”, во-вторых, сравнительно-исторический.

Тарановский вслед за А. П. Щаповым утверждал, что „для выяснения феодальной иерархии во всех ее деталях потребуется подробное изучение феодальных отношений по отдельным русским землям"89, а поскольку „феодализм опирается на экономические отношения, вытекающие из близкого, соседского [...] соприкосновения лиц и земель”, то именно „областное” (или „партикуляристическое”) изучение этого феномена будет значительно плодотворнее изучения, „отправляющегося от крупных центров и нивелирующего все местные особенности" 90 . В отличие от другого подразделения киевской школы - школы В. Б. Антоновича, Тарановский настаивал на перспективности „областного” изучения прежде всего социально-экономических, а уже затем политических отношений.

87 Ф. В. Тарановский, Феодализм в России, с. 30.

88 М. Ф. Владимирский-Буданов, Обзор истории русского трава, Киев 1888 , c. 115 .

89 Стоит отметить, что Тарановский не придавал понятию „земля” костомаровского смысла этнографического и духовного единства, считая ее только историко-территориальнмм термином. Более того, преувеличенное внимание к этому понятию в концепции Н. И. Костомарова, написание слова „Земля” с заглавной буквы называлось им „политическим фетишизмом” (Ф. В. Тарановский, Отзыв о сочинении В. И. Сергеевича..., с. 57, Прим. 1).

90 Ф. В. Тарановский, Феодализм в России, с. 41-43. 
Что касается сравнительно-исторического метода, то Тарановский, безусловно, не был пионером в исследовании феодализма на Руси, поскольку Павлов-Сильванский построил на нем всю свою концепцию ${ }^{91}$. Но, как полагал Тарановский, сравнение ранее проводилось или по отдельным территориям (только юго-запад или только северо-восток), или не всегда корректно: Павлов-Сильванский, например, проводил параллели между различными хронологическими периодами: Францией Карла Великого и Россией Ивана Грозного ${ }^{92}$. Тарановский предложил подвергнуть сравнительному анализу Московский период истории России и соответствующие по хронологии эпохи истории Западной Европы, при этом он предполагал, что политико-правовой строй Руси „быть может, свободно уляжется в общие рамки сословно-монархического государства, в свое время сложившегося на почве феодализма"93. Важно отметить, что Павлов-Сильванский приходил к почти тем же самым выводам, но Тарановский призывал их доказывать более строго и корректно. (Ср.: „Наш государственный порядок Московской эпохи XVI-XVII вв. вырос, так же как на Западе, из порядка феодального". Н. П. Павлов-Сильванский, Феодализм в Древней Руси, СПб. 1907, с. 140).

Таким образом, Тарановский фактически наметил программу изучения средневековой Руси, которую сам же и попытался выполнить в более поздних работах, в течение четверти века регулярно, хотя и нечасто, выходящих в свет.

Тарановский исходил из безусловного сословно-монархического характера Московского государства, придерживаясь тем самым концепции Леонтовича. Он полагал, что „после подавления боярской олигархии и окончательной гибели политического значения бояр в Смутное время московские цари вынуждены обратиться к сословному представительству, и время существования последнего составляет особый своеобразный период в истории русской государственной власти. Это период сословной монархии" следующие черты такого государственного устройства: 1) формаль-

91 См.: В. А. Муравьев, Теории феодализма в русской историографии кониа XIX - начала XX в. Автореф. дисс. канд. ист. наук., М. 1969, с. 19.

92 Ф. В. Тарановский, Феодализм в России, с. 38, 43.

93 Там же, с. 53.

94 Ф. В. Тарановский Рец., Рожков Н. Происхождение самодержавия в России, М. 1906, „Юридическая библиография”, Ярославль 1907, № 1, с. 5. 
ную независимость церкви, „высшим достижением «военного строя и исполнения личного состава подчиненных чего было 'двоевластие' XVII века»; 2) сословную систему государственных органов” и 3) соучастие сословий „в отправлении функций верховной власти (Боярская Дума, Освященный Собор, земские соборы)". Все это Тарановский был склонен называть „стариной”,95 (принцип „старины”, то есть традиционного сохранения институтов власти). К сословиям, „соучаствовавшим" в управлении государством, Тарановский относил духовенство, служилых людей по отечеству, посадских людей и черносошных крестьян. Сословно-представительный характер монархии XVII в. не означал, по Тарановскому, ограничения царской власти. Земские соборы были „столько же противовесом, сколько и орудием власти государя" 96 .

Сравнивая земские соборы с западноевропейскими представительными учреждениями (особенно, с Генеральными Штатами во Франции) Тарановский, как В. Н. Латкин и В. И. Сергеевич, в отличие от Б. Н. Чичерина и В. О. Ключевского, находил немало общего, но при этом подчеркивал и отличия, так как различался сам сословный строй Московского государства, „основывавшийся не на исторических привилегиях сословий, а на «неподвижном крепостном уставе» принудительной службы всех чинов государю”. Однако он высказывал близкую к Ключевскому мысль, что „служебное представительство XVI в. было ничем иным, как новым видом службы дворян, помещиков, гостей и торговых людей, служивших на Москве". Что касается выборного представительства XVII в., то оно „зародилось под влиянием вынужденной обстоятельствами Смутного времени политической самодеятельности «земли» и могло поэтому развиться в субъективное политическое право чинов на участие во власти". Последнее предположение, с одной стороны, намечает альтернативный путь развития страны, а с другой - перекликается с современными Тарановскому политическими событиями, участием „чинов во власти” через Государственную Думу. Но реализоваться этот вариант не смог. После Смуты „выборное представительство

95 Ф. В. Тарановский, Обеспечение прав служилого землевладения в сословно-монархическом строе Московского государства, Львов 1925, с. 11.

96 Ф. В. Тарановский, Соборное избрание и власть великого государя в XVII столетии, ЖМЮ 1913, № 5, с. 34. 
вновь стало лишь одним из видов службы, которую несли крепкие государю чины".

Тарановский считал, что власть московского царя „покоилась на началах теократических и вотчинных”, которые уживались с „началом соборного избрания”. Под ,теократическим” началом историк понимал „богоданность власти", , что касается „вотчинных” начал, то, по его мнению, „вся административная и даже политическая организация Московского государства [...] представляет собою только надстройку над замкнутыми частновладельческими вотчинами, которые составляли основу всего общественного уклада и были если не государствами в государстве, то, во всяком случае, своеобразными автономными частями государственного организма"98. Подобное положение сохранялось, по мысли Тарановского, вплоть до падения крепостного права. Таким образом, как справедливо отмечал Л. В. Черепнин, Тарановский, вслед за Павловым-Сильванским, противопоставлял сословную монархию феодализму и не считал возможным говорить о чертах феодализма в Московском государстве, ограничивая его только удельно-вечевым периодом ${ }^{99}$.

Различая смысловое содержание понятий „властвование” и „правление”, Тарановский относил термин „сословная монархия” к терминологическому полю первого из них. По форме же правления государства могли быть (по И. Канту) законными и деспотическими. Россия XVII в., безусловно, „не являлась «законной монархией», представляя собой «деспотическое» государство, ибо свобода личности и неприкосновенности частной собственности по отношению к государству и его интересам не находили себе в нем принципиального признания" 100 . Правда, стоит отметить, что несколько позднее Тарановский обнаружил некоторые начала неприкосновенности личности и частной собственности в Соборном Уложении 1649 г., однако общая характеристика формы правления изменена им не была ${ }^{101}$.

В конце 20-х гг. Тарановским были несколько изменены акценты в трактовке феодализма. Общий поворот от экономизма привел

97 Ф. В. Тарановский, Соборное избрание...

98 Ф. В. Тарановский Рец., Греков Б. Д. Новгородский дом Св. Софии, с. 332.

99 Л. В. Черепнин, Земские соборы Русского государства в XVI-XVII вв., M. 1978 , с. $25-26$.

100 Ф. В. Тарановский, Обеспечение..., с. 13.

101 Ф. В. Тарановский, Элементы..., с. 53. 
к усилению юридизма в определении этого явления. „Феодализм есть некоторая общая историко-юридическая категория, покрывающая собою великое разнообразие идиографических проявлений единого принципа дробления власти" - писал Тарановский. При этом само дробление власти отнюдь не следует понимать как результат разложения какого-то предшествующего единства власти, а напротив, как расширение власти по территории, как преодоление „,сопротивления пространства организующей силой политического строительства"102 . Поэтому теперь Тарановский склонялся к разделению феодальных отношений на режим сеньориальный и собственно феодальный, что было характерно и для Павлова-Сильванского: „на Руси, как и в Западной Европе, феодальный политический строй слагался из двух слоев - верхнего вассального и нижнего сеньориального; в XVI в. окончательно пал строй вассальный, или феодальный в тесном смысле этого слова, а строй сеньориальный остался и даже окреп: так было на Руси, так было и на Западе" экономическом содержании феодализма уже не говорилось. Подводя итог, следует отметить, что Тарановский принадлежал к безусловным сторонникам русского феодализма. Под воздействием Павлова-Сильванского он сформулировал собственную, несколько отличную от теории предшественника, концепцию, занявшую достойное место среди многочисленных научных построений гуманитариев в начале XX в. В 1916 г. он заметил, что история русского права „страдает от архивных переложений и нуждается в мысли, идее, хотя бы конструктивно-юридической" ${ }^{104}$. Без сомнения, творчество Тарановского стало важным шагом в этом направлении.

\section{Summary}

The paper is devoted to the life and activities of an outstanding historian of law and state, F. W. Taranowski (1875-1936), a disciple of F. I. Leontiev. F. W. Taranowski graduated form the Warsaw University to become recognized as a researcher of German and French law of $18^{\text {th }}$ century. He wrote numerous books on the theory and encyclopedia of law, including the famous handbook published in 1917 and reprinted in 1923. After the revolution of 1917 Taranowski emigrated to Yugoslavia. He lectured at the Belgrade University and he wrote several books and papers on the history of law of Southern Slavs.

102 Там же, с. 65.

103 Там же, с. 66-67. См. также: В. А. Муравьев, Указ. соч., с. 20.

104 ИР ЦНБ, Ф. ІІІ, № 56800, Л. 4. 


\section{Streszczenie}

Artykuł jest poświęcony życiu i działalności wybitnego historyka prawa i państwa F. W. Taranowskiego (1875-1936), ucznia F. I. Leontiewa, F. W. Taranowski był absolwentem Uniwersytetu Warszawskiego, uznanie zdobył jako badacz prawa niemieckiego i francuskiego XVIII wieku. Napisał szereg książek z dziedziny teorii i encyklopedii prawa, w tym słynny podręcznik, wydany w roku 1917 i ponownie w roku 1923. Po rewolucji 1917 roku Taranowski znalazł się na emigracji w Jugosławii. Wykładał na uniwersytecie w Belgradzie i napisał kilka książek i artykułów o historii prawa południowych słowian. 